\title{
'Althea Gyles', \\ in A Treasury of Irish Poetry in the English Tongue, ed. Stopford A. Brooke and T. W. Rolleston (1900)
}

Miss Althea Gyles may come to be one of the most important of the little group of Irish poets who seek to express indirectly through myths and symbols, or directly in little lyrics full of prayers and lamentations, the desire of the soul for spiritual beauty and happiness. She has done, besides the lyric I quote, which is charming in form and substance, a small number of poems full of original symbolism and spiritual ardour, though as yet lacking in rhythmical subtlety. ${ }^{1}$ Her drawings and book-covers, in which precise symbolism never interferes with beauty of design, are as yet her most satisfactory expression of herself. $^{2}$

W. B. Yeats 